\title{
Effects of oxygen, growth state, and senescence on the antioxidant responses of WI-38 fibroblasts
}

\author{
Arthur K. Balin • Richard J. Reimer • \\ Wende R. Reenstra • Steven M. Lilie • Ina Leong • \\ Katherine Sullivan • Robert G. Allen
}

Received: 11 February 2010 / Accepted: 26 April 2010 /Published online: 15 May 2010

(C) The Author(s) 2010. This article is published with open access at Springerlink.com

\begin{abstract}
Mitotically active, growth-arrested cells and proliferatively senescent cultures of human fetal lung fibroblasts (WI-38) were exposed to six different oxygen tensions for various lengths of time and then analyzed to determine the responses of their antioxidant defense system. Glutathione (GSH) concentration increased as a function of ambient oxygen tension in early passage cultures; the effect was larger in exponentially growing cultures than in those in a state of contactinhibited growth arrest, but was absent in senescent cells. Conversely, the activity of glutathione disulfide reductase was greater in growth-arrested cultures than in mitotically active cells irrespective of oxygen tension.
\end{abstract}

A. K. Balin $(\bowtie) \cdot$ R. J. Reimer • W. R. Reenstra •

S. M. Lilie $\cdot$ I. Leong $\cdot$ R. G. Allen

Laboratory for Investigative Dermatology,

The Rockefeller University,

1230 York Avenue,

New York, NY 10021, USA

e-mail: akbalin@balin.com

Present Address:

A. K. Balin $\cdot$ K. Sullivan $\cdot$ R. G. Allen

Longevity Achievement Foundation,

110 Chesley Drive,

Media, PA 19063, USA

Present Address:

R. J. Reimer

Department of Neurology and Neurological Sciences,

Stanford University,

Stanford, CA 94305, USA
Glucose-6-phosphate dehydrogenase was lowest in logphase cells exposed to different oxygen tensions for $24 \mathrm{~h}$ and in senescent cells. Both hypoxia and hyperoxia depressed selenium-dependent glutathione peroxidase activity in early passage cultures, while the activity of the enzyme progressively declined with increasing oxygen in senescent cells. The GSH $S$-transferase activity was unresponsive to changes in ambient oxygen tension in either young or senescent cultures. Manganesecontaining superoxide dismutase (MnSOD) activity was unaffected by oxygen tension, but was elevated in young confluent cultures as compared with cultures in log-phase growth. MnSOD activity was significantly

Present Address:

W. R. Reenstra

New England Inflammation and Tissue Protection Institute, Departments of Biology and Pharmaceutical Sciences, Northeastern University,

134 Mugar Building, 360 Huntington Avenue,

Boston, MA 02115, USA

Present Address:

S. M. Lilie

York Hospital,

1001S George St,

York, PA 17403, USA 
higher in senescent cultures than in early passage cultures and was also responsive to increased oxygen tension in senescent cultures. Copper-zinc-containing superoxide dismutases activity was not affected by oxygen tension or the passage of time, but it declined in senescent cultures.

Keywords Oxygen - Antioxidant defenses .

Senescence · WI-38 - Fibroblasts · Glucose-6-

phosphate dehydrogenase $\cdot$ Superoxide dismutase .

Glutathione - GSSG reductase - Glutathione

peroxidase $\cdot$ Reactive oxygen species

\section{Introduction}

At concentrations exceeding atmospheric level, oxygen is toxic to all organisms (Stogner and Payne 1992; Patel et al. 2003; Auten and Davis 2009). In fact, sub-atmospheric concentrations of oxygen are toxic at a cellular level (Balin et al. 1984, 2002b). Numerous studies have demonstrated oxygen toxicity in a broad spectrum of intact organisms as well as in a variety of cell culture models (for reviews, see Davies 1999, 2000; Greabu et al. 2008). An examination of the phenomenon at a cellular level reveals that specific points in cell cycle are oxygen sensitive (Balin et al. 1978; Rancourt et al. 2002). Both aerobic and anaerobic metabolism can be modulated profoundly by changes in ambient oxygen concentration (Balin et al. 1976). Aging of intact organisms is widely believed to be influenced by by-products of oxygen metabolism such as oxygen-centered free radicals and other non-radical reactive oxygen species (ROS; Allen and Balin 2003a).

Aging of cells in a culture environment manifests as limited proliferative capacity. Proliferative lifespan appears to be partly determined by loss of telomere DNA with each successive round of mitosis (Harley et al. 1990; Allsopp and Harley 1995). However, it has been reported that the rate of telomere shortening in various types of cells is affected by oxidative stress and hyperoxia (von Zglinicki et al. 1995, 2000; Parrinello et al. 2003). Furthermore, the proliferative capacity of various types of human cells can be modulated by changes in the ambient oxygen tension (Balin et al. 2002a).

The underlying causes of oxygen toxicity have not been clearly established. A widely held view is that oxygen toxicity arises from increased oxygen free radical generation in cells (Beckman and Ames 1998; Mattar and Haffor 2009), and it has been observed that exposure to hyperoxia accelerates the accumulation of oxidative by-products such as lipofuscin (von Zglinicki et al. 1995), which would seem to support the hypothesis.

Aerobic cells have antioxidant defenses that remove ROS before they can inflict damage. These include superoxide dismutases (SOD) that remove superoxide radicals $\left(\mathrm{O}_{2}{ }^{-}\right)$and produce hydrogen peroxide $\left(\mathrm{H}_{2} \mathrm{O}_{2}\right.$; Allen 1998), and catalase and peroxidases that remove $\mathrm{H}_{2} \mathrm{O}_{2}$ (Keogh et al. 1996). The family of seleno-proteins referred to as GSH peroxidases (GPx) remove both $\mathrm{H}_{2} \mathrm{O}_{2}$ (Modrick et al. 2009) and lipid peroxides (Ran et al. 2006; ArsovaSarafinovska et al. 2009). The most prominent of these, GPx-1, can metabolize both organic and inorganic substrates (Arsova-Sarafinovska et al. 2009). Enzymic defenses that remove highly reactive hydroxyl radicals (HO) have never been identified, but non-enzymatic antioxidant defenses, such as tocopherol, urate, carotenoids, ascorbate, and glutathione (Keogh et al. 1996; Allen and Balin 2003a), can remove ROS including $\mathrm{HO}$ by reacting directly with them. Non-enzymic antioxidants can also break chain oxidation reactions (Beckman and Ames 1998). Of course, if ROS are the primary catalysts of oxygen toxicity, then antioxidant defenses should increase in response to increasing oxidant production resulting from elevated ambient oxygen tensions.

A variety of environmental factors, including ROS, are believed to contribute to senescence via mechanisms independent of telomere shortening, particularly in human cells (Cristofalo et al. 2000, 2004). The proliferative capacity of various types of human cells can be modulated by changes in the ambient oxygen tension (Balin et al. 2002a). The effects of oxygen on growth are also mediated by some culture-specific factors such as seeding density (Balin et al. 1984, 2002a).

The toxic effects of oxygen may be mediated by the balance between ROS generation and antioxidant response and may be influenced not only by the age of cultures, but also by their level of mitotic activity. The purpose of this study was to assess the influence of oxygen tension on the antioxidant defenses of fetal lung fibroblasts (WI-38) in both actively growing and quiescent growth states as well as in proliferatively senescent cultures. 


\section{Methods}

Cell lines Human diploid embryonic lung fibroblast cell strains WI-38 were obtained from Dr. Vincent J. Cristofalo of the Lankenau Center for Medical Research, Wynnewood, PA, USA.

Cell culture Cells were grown in Dulbecco's modified Eagle's medium (1 g/l glucose: Gibco Laboratories, Grand Island, NY, USA). Immediately before use, the medium was supplemented with L-glutamine $(2 \mathrm{mM}$; Flow Laboratories, Rockville, MD, USA) and fetal bovine serum (10\% vol/vol; KC Biologicals). Antibiotics were not used. Cultures were grown at $37^{\circ} \mathrm{C}$ in $75-\mathrm{cm}^{2}$ sealed polystyrene flasks (No 3024; Falcon Labware, Oxnard, CA, USA) containing $40 \mathrm{ml}$ medium $0.54 \mathrm{ml} / \mathrm{cm}^{2}$ and with a gas phase volume of $233 \mathrm{~cm}^{3}$. The cells were released from the plastic with trypsin $\left(0.25 \%\right.$; Flow Laboratories) in $\mathrm{Ca}^{2+}$ and $\mathrm{Mg}^{2+}$-free Hanks' balanced salt solution (M.A. Bioproducts, Walkersville, MD, USA). After suspension in medium containing $10 \% \mathrm{FBS}$, cell number was determined with a Coulter Counter (Coulter Electronics, Hialeah, FL, USA), and cells were then inoculated into appropriate vessels at a density of $10^{4}$ cells $/ \mathrm{cm}^{2}$.

Population doublings (PD) were calculated by comparing cell counts per vessel at seeding with counts at confluence (Cristofalo et al. 2000). The percentage of labeled nuclei was determined autoradiographically (Cristofalo et al. 2000) and monitored for mycoplasma contamination by the methods of Schneider and Stanbridge (1975) and by incubation of cells and media on selective agar (Flow Laboratories). All young cultures had completed less than $60 \%$ of their proliferative lifespan and were free of mycoplasma contamination by these criteria. Cell viability was determined using Trypan Blue dye exclusion (Freshney 1994).

Senescent cells Cells were deemed senescent when the population failed to double 4 weeks and three refeedings after seeding. In the studies reported here, enough cells were collected to seed T175 tissue culture vessels for experimental analysis of the effects of oxygen tension. Senescent cells were seeded and maintained in medium equilibrated with $5 \%$ oxygen. After 7 days, cultures were refed with medium that contained $0.5 \%$ serum and transferred to the different oxygen tensions. Cultures were harvested for analysis after 48-h exposure.

Antioxidant defenses: cell culture Cultures used to study antioxidant defenses in log phase were seeded at $10^{4}$ cells $/ \mathrm{cm}^{2}$ in T175 flasks, grown for 3 days in an atmosphere containing $5 \% \mathrm{CO}_{2}, 5 \% \mathrm{O}_{2}$, and $90 \%$ $\mathrm{N}_{2}$. The gas phase of the cultures was equilibrated with gas mixtures containing $5 \% \mathrm{CO}_{2}, 0 \%, 5 \%, 20 \%$, $35 \%, 50 \%$, or $95 \% \mathrm{O}_{2}$, and the balance $\mathrm{N}_{2}$, and transferred to one of six incubators (Heraeus, Tekmar Co., Cincinnati, OH, USA) maintained electronically at the oxygen tension used to equilibrate the flask. Each incubator was equipped with a Clark oxygen electrode and $\mathrm{CO}_{2}$ thermal conductivity detector to maintain the desired percentages of atmospheric oxygen and carbon dioxide. Incubators were calibrated each day by withdrawing a sample of gas and measuring the partial pressure of oxygen and carbon dioxide with a blood gas analyzer (model 113; Instrumentation Laboratory, Inc., Lexington, MA, USA). Cultures in log-phase growth were harvested for analysis at 24 or $48 \mathrm{~h}$. Cultures grown for measurement of antioxidant defenses in stationary phase were seeded at $10^{4}$ cells $/ \mathrm{cm}^{2}$ in $\mathrm{T} 175$ flasks and grown to confluence in an atmosphere containing $5 \% \mathrm{CO}_{2}, 5 \%$ $\mathrm{O}_{2}$, and $90 \% \mathrm{~N}_{2}$. When cultures had reached a stationary growth phase ( 7 days), they were refed with fresh medium that contained $0.5 \%$ fetal bovine serum and the gas phase equilibrated with gas mixtures containing $5 \% \mathrm{CO}_{2}, 0 \%, 5 \%, 20 \%, 35 \%, 50 \%$, or $95 \% \mathrm{O}_{2}$ with the balance $\mathrm{N}_{2}$. Cultures were harvested for analysis after 24-, 48-, 72-, 96-, or 168-h exposure. In all cases, a blood gas analyzer was used to determine the oxygen content of the flasks before harvest.

\section{Biochemical analysis}

Superoxide dismutase activity Superoxide dismutase activity was determined by a modification of the positive assay of Misra and Fridovich (1977) as previously described (Allen et al. 1995). Cells were suspended in $16.6 \mathrm{mM}$ potassium phosphate buffer, $\mathrm{pH} 7.8$, sonicated for $15 \mathrm{~s}$, and then centrifuged at $20,000 \times g$ for $30 \mathrm{~min}$. The supernatants were dialyzed overnight against $50 \mathrm{mM}$ potassium phosphate buffer, $\mathrm{pH}$ 7.0. A $100-\mu \mathrm{l}$ aliquot of homogenate (containing between 100 and $200 \mu \mathrm{g}$ protein) was added to a 
cuvette that contained $0.25 \mathrm{ml}$ riboflavin $(100 \mu \mathrm{M}$ in $16.6 \mathrm{mM}$ potassium phosphate buffer, $\mathrm{pH} 7.8$ ); to this was added $1.65 \mathrm{ml}$ of a $0.24 \mathrm{mM}$ solution of $o$ dianisidine. The absorbance of the samples was then determined. The cuvettes were then illuminated $2 \mathrm{~min}$ with two 15-W Sylvania black lights, and the absorbance was read immediately. The difference in absorbencies before and after illumination minus a blank was proportional to SOD activity. In order to determine manganese-containing superoxide dismutase (MnSOD) activity, homogenate was added to a reaction mixture that contained $1.5 \mathrm{mM} \mathrm{KCN}$ (which inactivates copper-zinc SOD ( $\mathrm{Cu} / \mathrm{Zn} \mathrm{SOD})$ ) about 5 min prior to illumination. The dianisidine assay was sensitive to the protein content of samples; the effect was linear at low protein concentrations, but undetected at higher protein concentrations. Therefore, an amount of bovine albumin equal to the average protein content of the samples was routinely added to all of the blanks. Also, addition of cyanide (to distinguish MnSOD) significantly increases the background change in absorbance; however, the color change observed with 1 unit MnSOD (minus the appropriate blank) was identical with or without cyanide. Hence, one unit of activity was taken to be the amount of SOD that yields a color change above background equal to the magnitude of the change observed in the blank used for total activity.

Glutathione (GSH + GSSG) The level of total glutathione was determined by the cycling method of Tietze (1969). In this procedure, homogenate (deproteinized with $10 \%$ perchlorate and neutralized with $\mathrm{K}_{3} \mathrm{PO}_{4}$ ), glutathione disulfide (GSSG) reductase, $\mathrm{NADPH}$, and 5,5'-dithiobis-2-nitrobenzoic acid were mixed in a cuvette and the color change monitored at $412 \mathrm{~nm}$. A standard curve was constructed with known amounts of GSSG and used to calculate the concentration of glutathione present in the homogenates. An attempt was made to determine GSSG concentration by first eliminating GSH with $2 \%$ 2-vinylpyridine according to the method of Griffith (1980) and then repeating the above assay. However, the concentration of GSSG in the fibroblast cell lines examined was low and often below the detection limits of the assay.

GSSG reductase A slight modification of the method of Carlberg and Mannervik (1985) was used to determine GSSG reductase (GR) activity. Homoge- nate was added to a solution of $200 \mathrm{mM}$ potassium phosphate buffer containing $0.2 \mathrm{mM}$ NADPH and $2 \mathrm{mM}$ GSSG. The rate of color loss monitored at $340 \mathrm{~nm}$ is proportional to GSSG reductase activity.

Glucose-6-phosphate dehydrogenase Glucose-6phosphate dehydrogenase (G-6-PD) activity was quantified according to the method of Deutsch (1980), which is based on the formation of NADPH. Maleimide $(1 \mathrm{mM})$ was added to block competing reactions. NADPH formation was determined spectrophotometrically at $340 \mathrm{~nm}$.

GSH peroxidase (GPx-1) This assay couples the oxidation of GSH by GSH peroxidase to the oxidation of NADPH by GSH reductase as previously described (Keogh et al. 1996). The assay mixture contained $50 \mathrm{mM}$ Tris $\mathrm{HCl}$, pH 7.6; 1 unit/ml GSSG reductase, $0.25 \mathrm{mM}$ GSH, $0.2 \mathrm{mM}$ NADPH, and $3 \mathrm{mM} \mathrm{KCN}$ to increase stability. The reaction was initiated by the addition of $50 \mu \mathrm{l}$ of a $12 \mathrm{mM} \mathrm{H}_{2} \mathrm{O}_{2}$ solution. This method detected predominantly type 1 GPx activity. One unit of activity is equal to consumption of $1 \mu \mathrm{M}$ $\mathrm{NADPH} / \mathrm{min}$ (monitored at $340 \mathrm{~nm}$ ). Due to the relatively low GPx activity observed in fibroblasts, we report activity in milliunits.

GSH S-transferases Activity of $S$-transferases was determined using 1-chloro-2, 4-dinitrobenzene (CDNB) as a general substrate (Hazelton and Lang 1983). The assay mixture consisted of $50 \mu \mathrm{l}$ of homogenate, $100 \mu \mathrm{l}$ of $50 \mathrm{mM} \mathrm{GSH}$, and $450 \mu \mathrm{l}$ of CDNB (to a final concentration of $1.25 \mathrm{mM}$ ). The rate of increase in absorbance at $340 \mathrm{~nm}$ was used to calculate activity using $9.6 \mathrm{mM}^{-1} \mathrm{~cm}^{-1}$ as an extinction coefficient. Units of activity are expressed as nmol $\min ^{-1} \mathrm{mg}$ protein ${ }^{-1}$.

ROS generation The rate of ROS generation was determined using 2',7'-dichlorofluorescin diacetate (DCFH-DA). Because it is non-polar, cell membranes are permeable to DCFH-DA (Bass et al. 1983); once in cells, the compound is desacetylated to DCFH. DCFH is polar and is thus trapped in cells. DCFH is oxidized predominantly by $\mathrm{H}_{2} \mathrm{O}_{2}$ to the highly fluorescent 2',7'-dichlorofluorescein (Bass et al. 1983; Chiou and Tzeng 2000). The oxidation of DCFH to DCF has been widely used to determine $\mathrm{H}_{2} \mathrm{O}_{2}$ generation by flow cytometry and direct 
visualization techniques (Rothe and Valet 1990, 1994; Carter et al. 1994). However, the indicator is not entirely specific to $\mathrm{H}_{2} \mathrm{O}_{2}$ (Liochev and Fridovich 2001); therefore, we shall refer to this measurement as ROS rather than $\mathrm{H}_{2} \mathrm{O}_{2}$ generation.

DCFH-DA was initially solubilized in $250 \mu \mathrm{l}$ DMSO and then added to $150 \mathrm{ml}$ phenyl red, serum-free MEM. WI-38 cells were seeded in a black 96-well viewplate (Perkin Elmer, Waltham, MA, USA) at 10,000 cells per well. The cells were washed once with phenyl red, serum-free MEM and then treated with $100 \mu \mathrm{l}$ of DCFH-DA containing medium. The plates were incubated at $37^{\circ} \mathrm{C}$ for $1 \mathrm{~h}$. Following incubation, the cells were washed once with the wash buffer and read (ex 494, em 518) with a Victor 2 Plate Reader (Perkin Elmer). Filters used were ex 485 (Perkin Elmer Filter 11440022) and em 535 (Perkin Elmer Filter 11440023). Protein in the samples was determined using Bradford protein assay reagent (Biorad). The reagent was diluted 1:5 with ultrapure water and filtered prior to treating samples. The Victor 2 plate reader was used to determine absorbance at $595 \mathrm{~nm}$. Standard curves were prepared for each assay from known concentrations of DCF and protein.

Statistics All measurements were performed on triplicate samples in each experiment, and all experiments were repeated at least twice. Data were compared using analysis of variance (ANOVA). Least significant difference (LSD) was used to distinguish subgroups. In all cases, $p \leq 0.05$ was inferred to indicate significance.

\section{Results}

Superoxide dismutases

Copper-zinc SOD The average activity of copperzinc SOD $(\mathrm{Cu} / \mathrm{Zn} \mathrm{SOD})$ was relatively constant at $1.6 \mathrm{U} / \mathrm{mg}$ protein regardless of ambient oxygen tension or the duration of exposure. The activity of this enzyme was also independent of the growth state of the cells. Senescent cultures exhibited decreased $\mathrm{Cu} / \mathrm{Zn}$ SOD activity of $0.7 \mathrm{U} / \mathrm{mg}$ protein. As in the case of early passage cells, the activity of this enzyme was not affected by increased oxygen tension.
Manganese superoxide dismutase The manganesecontaining form of superoxide dismutase is mitochondrial and thus is pivotal to the removal of $\mathrm{O}_{2}{ }^{-}$. MnSOD was unaffected by oxygen tension in any of the groups of young cultures examined in this study (Fig. 1); however, growth state and proliferative age strongly influenced the activity of this enzyme. Logphase cultures were statistically similar at all of the

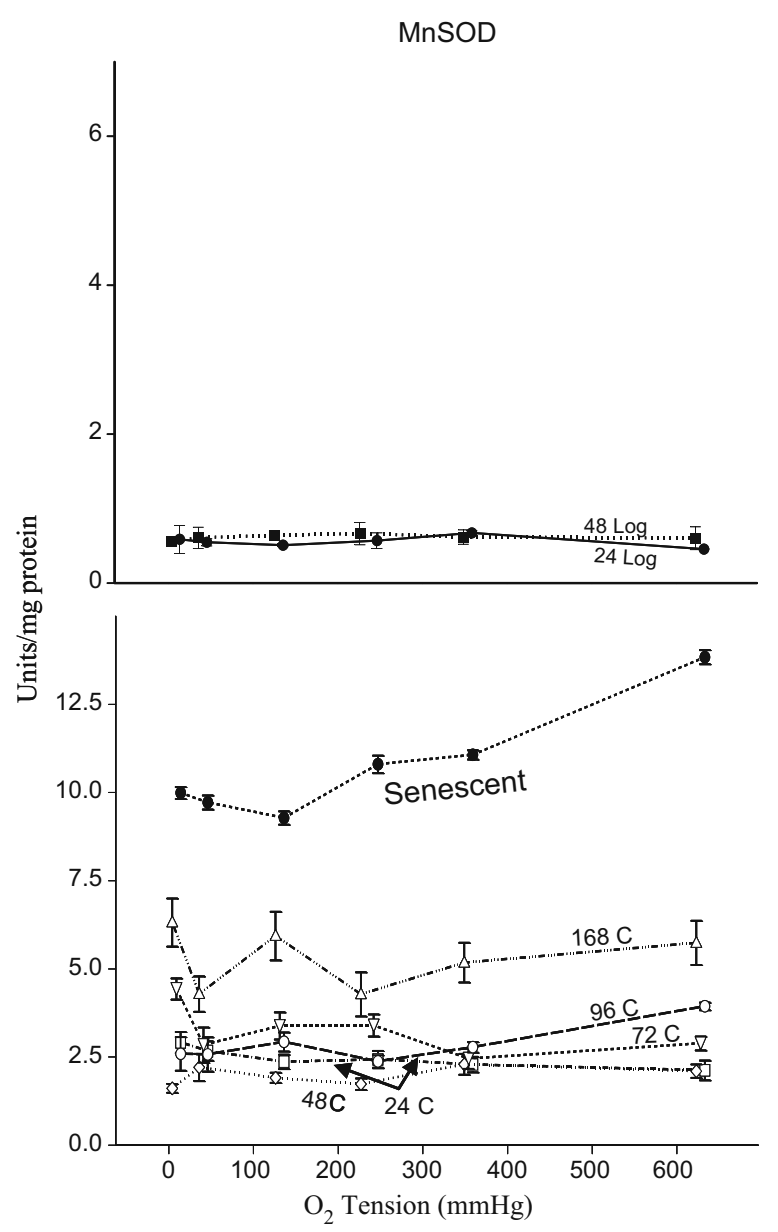

Fig. 1 MnSOD activity in WI-38 cultures exposed to different oxygen tensions for various periods of time. Mitotically active cultures were grown 3 days at under an ambient oxygen tension of $38 \mathrm{~mm} \mathrm{Hg}$ then refed and transferred to the different oxygen tensions for 24 or $48 \mathrm{~h}$ ( $24 \mathrm{Log}$ and $48 \mathrm{Log}$; upper panel). Nongrowing cultures were grown to saturation density under $5 \%$ oxygen, refed with medium that contained $0.5 \%$ serum, and then transferred to different oxygen tensions. The nonproliferating, confluent (C) cultures were harvested and analyzed after 24, 48, 72, 96, and $168 \mathrm{~h}(24 \mathrm{C}, 48 \mathrm{C}, 72 \mathrm{C}$, $96 \mathrm{C}$, and $168 \mathrm{C}$; lower panel). Senescent cultures were harvested after 48 -h exposure to different oxygen tensions (see "Methods") 
oxygen tensions examined (ANOVA, LSD, $p \geq 0.7$ in all cases; Fig. 1, upper panel), but they exhibited significantly lower MnSOD activity than growtharrested cultures maintained at corresponding oxygen tensions (ANOVA, LSD, $p \leq 0.00001$ in all comparisons). It was also observed that, in growth-arrested cultures, MnSOD activity accumulated with the passage of time, albeit the relationship was not linear (Fig. 1, lower panel). Confluent (C), growth-arrested cultures exposed to different oxygen tensions for $24 \mathrm{~h}$ (24 C) exhibited significantly greater MnSOD activity than similar cultures exposed for $48 \mathrm{~h}(48 \mathrm{C})$ at oxygen tensions of 9 and $242 \mathrm{~mm} \mathrm{Hg}$ (ANOVA, LSD, $p=0.00002$ and $p=0.01$, respectively; Fig. 1, lower panel). The cultures maintained at other oxygen tensions in the $24 \mathrm{C}$ group also tended to exhibit greater MnSOD activity than the corresponding cultures in the $48 \mathrm{C}$ group, but the differences were not statistically significant. Growth-arrested cultures exposed to different oxygen tensions for $72 \mathrm{~h}$ (72 C) exhibited significantly greater MnSOD activity than observed in the $24 \mathrm{C}$ or $48 \mathrm{C}$ groups at all oxygen tensions ( $p \leq 0.02$ in all cases) except $41 \mathrm{~mm} \mathrm{Hg}$ where the $24 \mathrm{C}$ group was similar (ANOVA, LSD, $p=$ $0.5)$ and $354 \mathrm{~mm} \mathrm{Hg}$ where both 24 and $48 \mathrm{C}$ were similar to $72 \mathrm{C}$ (ANOVA, LSD, $p \leq 0.5$ in both cases). Growth-arrested cultures exposed for $96 \mathrm{~h}$ (96 C) exhibited greater MnSOD at 9 (ANOVA, LSD, $p=$ 0.000001 ), 242 (ANOVA, LSD, $p=0.003$ ), and $628 \mathrm{~mm} \mathrm{Hg}$ oxygen (ANOVA, LSD, $p=0.0008$ ) than cultures in the $72 \mathrm{C}$ group exposed to similar oxygen tensions. Cells maintained under different oxygen tensions for $168 \mathrm{~h}(168 \mathrm{C})$ exhibited significantly greater MnSOD activity than cultures maintained at corresponding oxygen tensions for shorter periods of time (ANOVA, LSD, $p \leq 0.0001$ in all cases; Fig. 1, lower panel). Since oxygen tension failed to stimulate enzyme activity in early passage cultures, it is inferred that MnSOD activity passively accumulated in quiescent cultures. Cultures of senescent cells exhibited higher MnSOD activity than proliferatively younger cultures at all oxygen tensions (ANOVA, $p<0.0001$ in all cases). MnSOD activity was also induced by hyperoxia in senescent cultures $\left(p \mathrm{O}_{2}=633 \mathrm{~nm}\right.$; ANOVA, $p<0.001$ in all comparisons with other oxygen tensions; Fig. 1, lower panel).

Glutathione Large volumes of medium surround cells in culture. Because cell membranes are partially permeable to oxidized glutathione (GSSG), it diffuses from cells into the relatively large volume of medium that surrounds them, leaving only extremely low concentrations of GSSG in normal cells. The concentration of GSSG was often near or below the limit of detection of the assay. Consequently, nearly all of the glutathione present in cells is in the reduced form (GSH). For the remainder of this discussion, we will refer to total glutathione as GSH.

In young cells, the concentration of GSH increased as a function of the ambient oxygen concentration; however, the effect was much more pronounced in log-phase cultures (Fig. 2, upper panel).

Hence, the greatest increase in GSH concentration was observed in log-phase cultures exposed to different $\mathrm{O}_{2}$ partial pressures for $24 \mathrm{~h}(24 \mathrm{Log})$, and the next greatest was observed in log-phase cultures exposed to different $\mathrm{O}_{2}$ partial pressures for $48 \mathrm{~h}(48 \mathrm{Log})$. The relative response to ambient oxygen tension was diminished in stationary phase (non-dividing) cultures. The least responsive cells were those in stationary phase cultures exposed to different oxygen tensions for only $24 \mathrm{~h}$ ( $24 \mathrm{C}$; see Fig. 2, lower panel). In all cases except the growth-arrested cultures exposed for $24 \mathrm{~h}$ (24 C), the GSH concentration present in cells maintained at $9 \mathrm{~mm} \mathrm{Hg}$ was significantly lower than the concentration of GSH found in cells maintained at oxygen tensions of $131 \mathrm{~mm} \mathrm{Hg}$ or greater (ANOVA, $p<0.03$ in $48 \mathrm{C}$ group and $p<0.00001$ in all other cases). Cultures of proliferating cells maintained at oxygen partial pressure of $9 \mathrm{~mm} \mathrm{Hg}$ for $24 \mathrm{~h}(24 \mathrm{Log})$ also tended to exhibit lower GSH than cultures maintained at $41 \mathrm{~mm} \mathrm{Hg}$ oxygen than at $131 \mathrm{~mm} \mathrm{Hg}$ oxygen (ANOVA, $p=0.00001$ ). Conversely, confluent, growth-arrested cultures maintained under oxygen partial pressures of 9, 41, 131, and $242 \mathrm{~mm} \mathrm{Hg}$ for $24 \mathrm{~h}$ (24 C) exhibited statistically similar concentrations of GSH (Fig. 2, lower panel). Furthermore, in all of the experiments in which it was examined (three experiments), the concentration of GSH was significantly lower ( $p \leq 0.001$ in all cases) in growth-arrested cultures maintained at an oxygen partial pressure of 131, 242, 324 , or $648 \mathrm{~mm} \mathrm{Hg}$ for only $24 \mathrm{~h}(24 \mathrm{C})$ than in confluent cultures maintained at these oxygen tension for longer periods (Fig. 2, lower panel). These data suggest that proliferating cultures produce more GSH as the oxygen tension increases than cultures of nondividing cells and that GSH concentration is lowest immediately after cultures reach confluence and the cells 


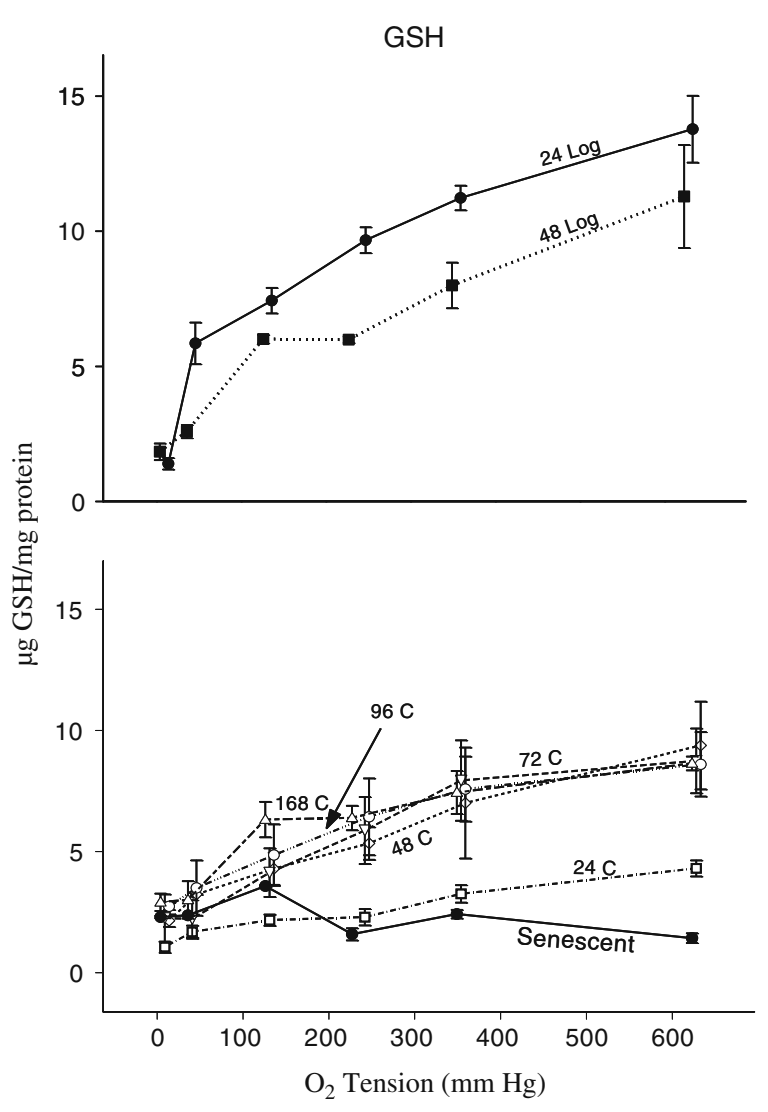

Fig. 2 GSH concentration in WI-38 cultures exposed to different oxygen tensions for various periods of time. Mitotically active cultures were grown 3 days under an ambient oxygen tension of $38 \mathrm{~mm} \mathrm{Hg}$ then were refed and transferred to the different oxygen tensions for 24 or $48 \mathrm{~h}$ prior to harvest and analysis (24 Log and $48 \mathrm{Log}$ ). Exposures of non-growing, confluent cultures to different oxygen tensions was achieved by growing cells to saturation density under $38 \mathrm{~mm} \mathrm{Hg}$ oxygen; the growth-arrested, confluent cultures (C) were then refed with medium that contained $0.5 \%$ serum and transferred to different oxygen tensions for $24,48,72,96$, or $168 \mathrm{~h}(24 \mathrm{C}, 48 \mathrm{C}, 72 \mathrm{C}$, $96 \mathrm{C}$, and $168 \mathrm{C}$; lower panel). Senescent cultures were harvested after 48-h exposure to different oxygen tensions (see "Methods")

enter a state of proliferative quiescence. Senescent cultures exhibited lower GSH concentrations at 247 , 359 , and $633 \mathrm{~nm} \mathrm{O}$ (ANOVA; $p<0.001$ in all comparisons with younger cultures; Fig. 2, lower panel). The results clearly indicate that unlike the results observed in early passage cultures, GSH concentration was not directly dependent on ambient $\mathrm{O}_{2}$ concentration in senescent cultures (Fig. 2, lower panel).

GSSG reductase (GR) reduces GSSG to GSH using electrons obtained from NADPH. In vivo, the enzyme plays an important role in maintaining redox balance. We examined whether GR activity could contribute to the large differences in GSH concentration that existed between actively growing and confluent, growth-arrested cultures by comparing both groups of actively growing cultures (24 Log and $48 \mathrm{Log}$ ) with the first two groups of growth-inhibited cultures (24 $\mathrm{C}$ and $48 \mathrm{C}$; Fig. 3). In contrast to GSH concentration (Fig. 2), GR activity was lower in logphase cells. Although increasing the $\mathrm{O}_{2}$ tension appeared to stimulate GR in growing cultures, there was no such effect in mitotically quiescent cells. Preliminary studies revealed no significant differences between mitotically quiescent cultures and senescent cells (at $134 \mathrm{~nm} \mathrm{Hg}$ oxygen tension), and no further comparison of oxygen effects was made for senescent cultures. On the basis of these results, we infer that the changes in GSH concentration in both mitotically active and quiescent cells were independent of GR activity in all of the cultures examined.

Glucose-6-phosphate dehydrogenase (G-6-PD) is an enzyme in the pentose shunt that is sensitive to feedback activation by GSSG (Eggleston and Krebs 1974; Legan et al. 2008). It is important for proper

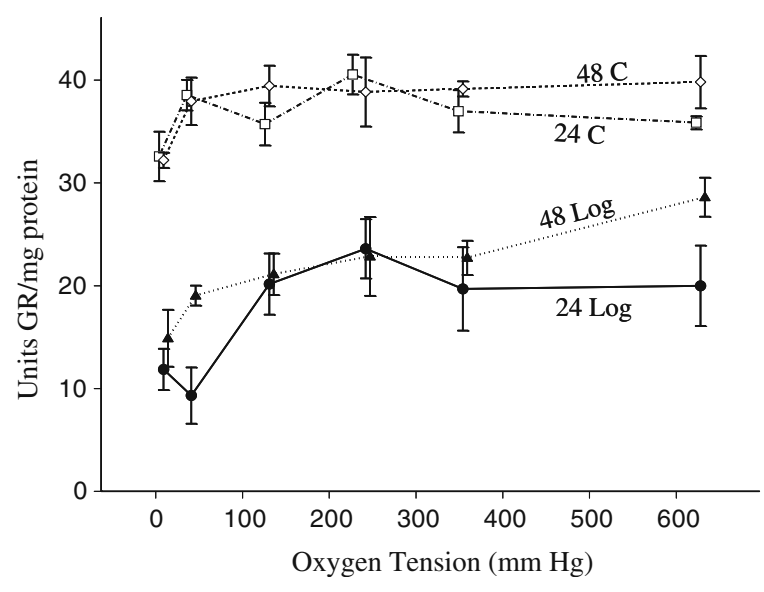

Fig. 3 GSSG reductase activity in WI-38 cultures exposed to different oxygen tensions for various periods of time. Mitotically active cultures were grown 3 days under an ambient oxygen tension of $38 \mathrm{~mm} \mathrm{Hg}$ then were refed and transferred to the different oxygen tensions for 24 or $48 \mathrm{~h}$ ( $24 \mathrm{Log}$ and 48 Log). Mitotically quiescent cultures were obtained by allowing them to grow to saturation density under $38 \mathrm{~mm} \mathrm{Hg}$ oxygen for 7 days. The resulting stationary phase, confluent cultures (C) were refed with medium that contained $0.5 \%$ serum and then transferred to different oxygen tensions for 24 or $48 \mathrm{~h}$ prior to harvest and analysis (24 C, $48 \mathrm{C}$ ) 
maintenance of GSH concentration in cells because it is involved in the synthesis of NADPH, the co-factor of GSSG reductase.

G-6-PD activity was greater in cells maintained under an oxygen tension of $324 \mathrm{~mm} \mathrm{Hg}$ than in cells maintained at $9 \mathrm{~mm} \mathrm{Hg}$ oxygen. The increase was statistically significant in the 48 Log (ANOVA, $p=0.002$; Fig. 4, upper panel), $72 \mathrm{C}$ (AVOVA, LSD, $p=0.003$; Fig. 4 , lower panel), $95 \mathrm{C}$ (AVOVA, LSD $p=$ 0.02; Fig. 4, lower panel), and $168 \mathrm{C}$ (AVOVA, LSD $p=0.02$; Fig. 4, lower panel) groups. G-6-PD activity also tended to be greater in growth-arrested cells

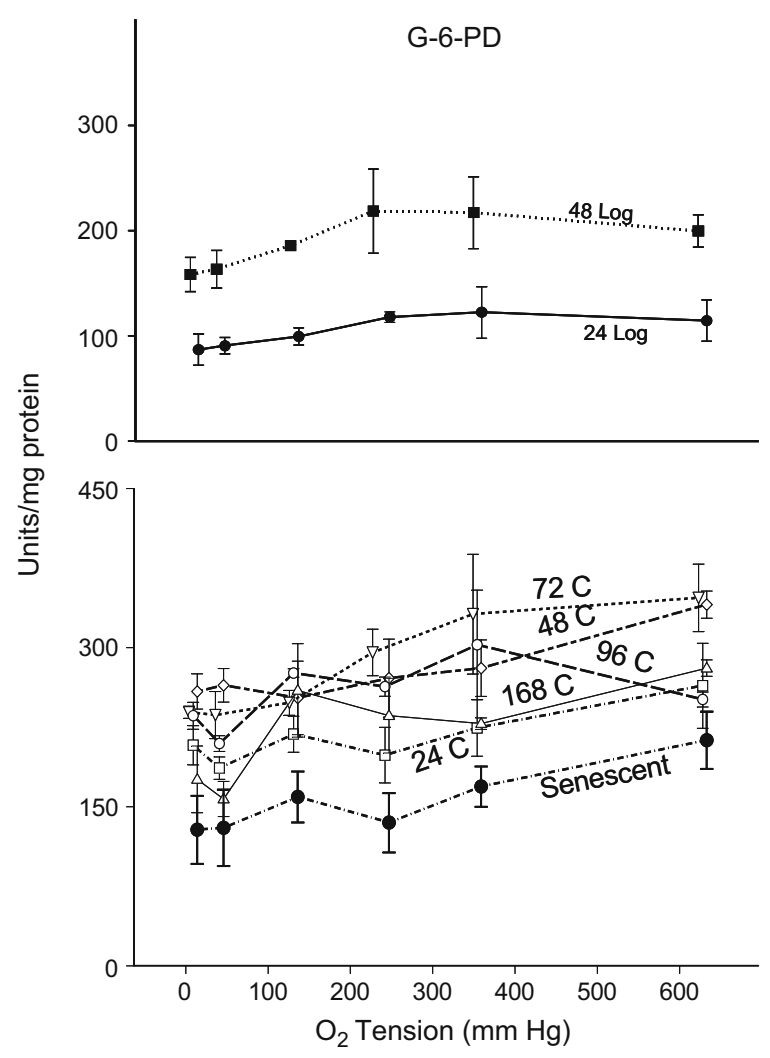

Fig. 4 G-6PD activity in WI-38 cultures exposed to different oxygen tensions for various periods of time. Mitotically active cultures were grown 3 days under an ambient oxygen tension of $5 \%$ then were refed and transferred to the different oxygen tensions for 24 or $48 \mathrm{~h}$ (24 Log and $48 \mathrm{Log}$; upper panel). Mitotically quiescent cultures were obtained by allowing them to grow to saturation density under $38 \mathrm{~mm} \mathrm{Hg}$ oxygen for 7 days. The resulting stationary phase, confluent cultures (C) were refed with medium that contained $0.5 \%$ serum and then transferred to different oxygen tensions for $24,48,72,96$, or $168 \mathrm{~h}(24 \mathrm{C}, 48 \mathrm{C}, 72 \mathrm{C}, 96 \mathrm{C}$, and $168 \mathrm{C}$; lower panel). Senescent cultures were harvested after 48 -h exposure to different oxygen tensions (see "Methods") maintained under an oxygen partial pressure of $648 \mathrm{~mm} \mathrm{Hg}$ as compared to cultures maintained under $9 \mathrm{~mm} \mathrm{Hg}$ oxygen in several of the groups, but the effect was less consistent than was observed in cells maintained under $324 \mathrm{~mm} \mathrm{Hg}$ oxygen (Fig. 4, lower panel).

Significant elevations of G-6-PD at $648 \mathrm{~mm} \mathrm{Hg}$ oxygen were observed in cultures from the $48 \mathrm{Log}$ (ANOVA, LSD, $p=0.04$ ), $24 \mathrm{C}$ (ANOVA, LSD, $p=$ 0.02), $72 \mathrm{C}$ (ANOVA, LSD, $p=0.002$ ), and $168 \mathrm{C}$ (ANOVA, LSD, $p=0.00002$ ) groups. G-6-PD tended to be lower in log-phase cells than in non-growing cultures. For example, G-6-PD activity was significantly lower in proliferating cultures exposed to different oxygen tensions for $24 \mathrm{~h}(\log 24)$ than in any other group of cultures (ANOVA, LSD, $p \leq 0.0001$ in all comparisons; Fig. 4, upper panel). The effect was far less pronounced in the Log 48 group, which exhibited similar G-6-PD activity to the $168 \mathrm{C}$ group at 9, 41, and $324 \mathrm{~mm} \mathrm{Hg}$ oxygen. The Log 48 group also exhibited higher activity than the $24 \mathrm{C}$ group when maintained under $242 \mathrm{~mm} \mathrm{Hg}$ oxygen. Nevertheless, the extremely low levels of G-6-PD in the Log 24 group and the fact that the Log 48 group exhibited activity that was relatively low as compared to most non-growing cultures suggested that the activity of the enzyme tended to become elevated as cells reached confluence and ceased to divide. Senescent cultures exhibited significantly lower (ANOVA, $p<0.001$; Fig. 4, lower panel) G-6-PD at all oxygen tensions except 14 and $46 \mathrm{~nm} \mathrm{O}_{2}$, where activity was similar between senescent cultures and cultures maintained at these oxygen tensions for $168 \mathrm{~h}$ (168 C). Activity was similar between the $24 \mathrm{C}$, $96 \mathrm{C}$, and senescent cultures at $633 \mathrm{~mm} \mathrm{Hg}$ oxygen tension (ANOVA, $p<0.09 ; p<0.1$ respectively).

Glutathione peroxidase (GPx-1) Selenium-dependent GPx-1 plays an important role in the removal of $\mathrm{H}_{2} \mathrm{O}_{2}$ from cells. This is particularly true in fetal lung fibroblasts because they tend to have relatively low levels of catalase activity. Also, the $K_{\mathrm{M}}$ of catalase is high (Nicholls et al. 2001), which probably necessitates the involvement of other enzymes such as GPx-1 to effectively remove $\mathrm{H}_{2} \mathrm{O}_{2}$. Additionally, GPx-1 can remove lipid peroxides. The enzyme requires GSH as a co-factor. In general, GPx-1 activity was higher in cultures maintained at either 41 or $131 \mathrm{~mm} \mathrm{Hg}$ oxygen as compared to cultures maintained under an oxygen partial pressure of $9 \mathrm{~mm} \mathrm{Hg}$ (Fig. 5). 


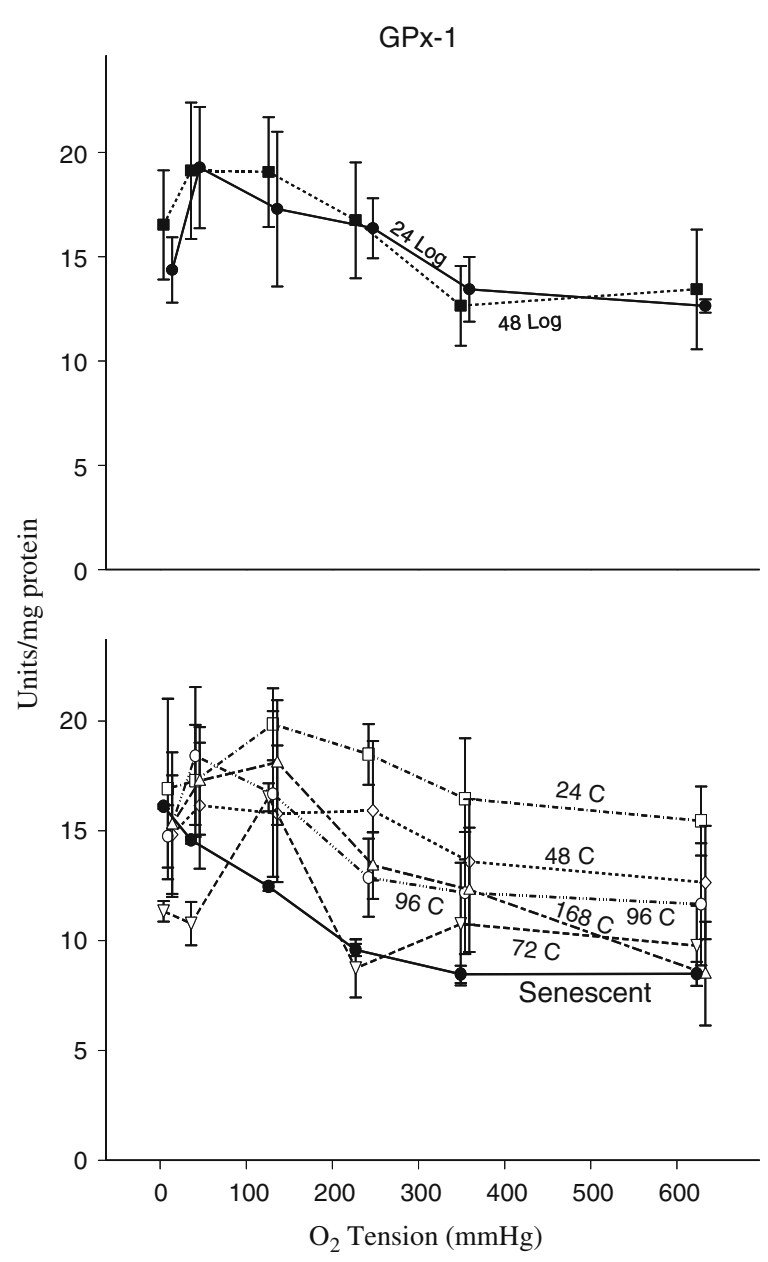

Fig. 5 GPx activity in WI-38 cultures exposed to different oxygen tensions for various periods of time. Mitotically active cultures were grown 3 days under an ambient oxygen tension of $5 \%$ then refed and transferred to the different oxygen tensions for 24 or $48 \mathrm{~h}(24 \mathrm{Log}$ and $48 \mathrm{Log}$; upper panel). Analysis of non-growing cultures was performed by allowing them to grow to saturation density under $5 \%$ oxygen; the confluent (C) cultures were refed with medium that contained $0.5 \%$ serum and then transferred to different oxygen tensions for 24, 48, 72, 96, and $168 \mathrm{~h}(24 \mathrm{C}, 48 \mathrm{C}, 72 \mathrm{C}, 96 \mathrm{C}$, and $168 \mathrm{C}$; lower panel). Senescent cultures were harvested after 48-h exposure to different oxygen tensions (see "Methods")

The difference was statistically significant in mitotically active cultures maintained at 9 and $41 \mathrm{~mm} \mathrm{Hg}$ oxygen for $24 \mathrm{~h}$ (ANOVA, LSD, $p=$ 0.005), growth-arrested cultures maintained under oxygen partial pressures of 9 and $131 \mathrm{~mm} \mathrm{Hg}$ for $72 \mathrm{~h}($ ANOVA, LSD, $p=0.01)$ and in growth-arrested cultures maintained under oxygen tensions of 9 and $41 \mathrm{~mm} \mathrm{Hg}$ for $96 \mathrm{~h}$ (ANOVA, LSD, $p=0.03$ ). There was also a tendency for high oxygen tension to slightly decrease GPx-1 activity. For example, actively growing cultures maintained at different oxygen tensions for $24 \mathrm{~h}$ exhibited a progressive loss of GPx-1 activity at oxygen tensions greater than $41 \mathrm{~mm} \mathrm{Hg}$. Furthermore, GPx-1 activity was significantly diminished at partial oxygen pressures of 324 and $648 \mathrm{~mm} \mathrm{Hg}$ (ANOVA, LSD, $p=0.001$ and 0.00002 , respectively) as compared to activity present under $41 \mathrm{~mm} \mathrm{Hg}$ oxygen. A similar pattern was observed in all of the groups. Specifically, GPx-1 activity was lower in cells maintained at 324 and $648 \mathrm{~mm} \mathrm{Hg}$ oxygen than in cultures maintained under $41 \mathrm{~mm} \mathrm{Hg}$ oxygen in the $48 \log$ (ANOVA, LSD, $p=0.0003,0.001$, respectively) and $24 \mathrm{C}$ groups (ANOVA, LSD, $p=0.04,0.007$, respectively). GPX-1 activity was significantly lower in the cultures of the $48 \mathrm{C}$ group maintained at $648 \mathrm{~mm} \mathrm{Hg}$ as compared to cultures maintained at $41 \mathrm{~mm} \mathrm{Hg}$ oxygen. GPx-1 activity was lower in the $72 \mathrm{C}$ group in cultures maintained at oxygen partial pressures of 242, 324, and 648 as compared with cultures maintained at $131 \mathrm{~mm} \mathrm{Hg}$ oxygen (ANOVA, LSD, $p=0.003,0.007,0.002$, respectively). GPx-1 activity was also significantly lower in the $96 \mathrm{C}$ and $168 \mathrm{C}$ groups maintained at oxygen partial pressures of 242, 324, and 648 as compared with cultures maintained at $41 \mathrm{~mm} \mathrm{Hg}$ oxygen (ANOVA, LSD, $p=$ $0.0008,0.0002,0.00006$ and $p=0.02,0.003,0.00001$, respectively). On the basis of these observations, we infer that elevated oxygen tension decreased GPx-1 activity. Activity was significantly greater at 9 and $41 \mathrm{~mm} \mathrm{Hg}$ oxygen in senescent cells than in the $72 \mathrm{C}$ group (ANOVA, $p<0.0001$ in both cases). However, GPx-1 activity declined steadily in senescent cultures as oxygen tension was increased (Fig. 5, lower panel). At $648 \mathrm{~mm} \mathrm{Hg}$ oxygen partial pressure, senescent cells exhibited GPx-1 activity that was significantly lower than all other groups except $72 \mathrm{C}$ and $168 \mathrm{C}$ (ANOVA, $p<0.08 ; p<0.9$ respectively).

Glutathione S-transferase The $S$-transferases are a family of enzymes that detoxify toxic substances by conjugating them with GSH. The most abundant $S$ transferase, ligandin, probably accounts for most of the activity we observed using CDNB as the substrate. Our results revealed that $S$-transferase activity was unaffected by oxygen tension and did not accumulate with the passage of time. The average activity of CDNB responsive $S$-transferase activity 
was $215.9 \pm 40.6 \mathrm{mU} / \mathrm{mg}$ protein. We observed no significant differences in any of the activities recorded. $S$-transferase activity was slightly, though not significantly higher in senescent cells at $291 \pm$ $48.8 \mathrm{mU} / \mathrm{mg}$ protein but, as in the case of young cultures, the activity of the enzyme was unresponsive to changes in ambient oxygen tension.

ROS generation In log-phase cultures, ROS levels were greatest at low oxygen tension ( $9 \mathrm{~mm} \mathrm{Hg}$; Fig. 6a). Addition of buthionine sulfoximine (BSO), which inhibits GSH synthesis, induced highly significant increases in ROS concentration at 9, 242, and $628 \mathrm{~mm} \mathrm{Hg} \mathrm{O}_{2}$.

Conversely, ROS concentration was generally higher in contact-inhibited stationary phase cultures, but addition of BSO produced little effect. The greatest ROS concentration in stationary phase cultures was observed at $131 \mathrm{~mm} \mathrm{Hg} \mathrm{O}$, whether or not cells were pretreated with BSO.

\section{Discussion}

In this study, we examined the influence of oxygen on the antioxidant enzyme responses of normal human fibroblasts. The results reveal that GSH concentration was consistently stimulated by increased oxygen tension. The effect was larger in exponentially growing cultures than in those that were in a state of contact-inhibited growth arrest. The activities of enzymes involved in maintenance of GSH concentration such as GR and G-6-PD failed to correlate with GSH concentration. G-6-PD activity was lower in 24 Log than in confluent cultures, but was lowest in senescent cultures. Both hypoxia and hyperoxia depressed GPx-1 activity in proliferatively young cells, while GPx-1 activity declined progressively as a function of oxygen tension in senescent cells. Oxygen tension did not influence the activity of the CDNB-sensitive $S$-transferases in any of the cultures. MnSOD was elevated in young non-proliferating cultures as compared with actively growing cells; it also accumulated with the passage of time, but failed to respond to changes in ambient oxygen tension. Conversely, MnSOD activity was much more elevated in senescent cultures and could be stimulated by high oxygen partial pressure. $\mathrm{Cu} / \mathrm{Zn}$

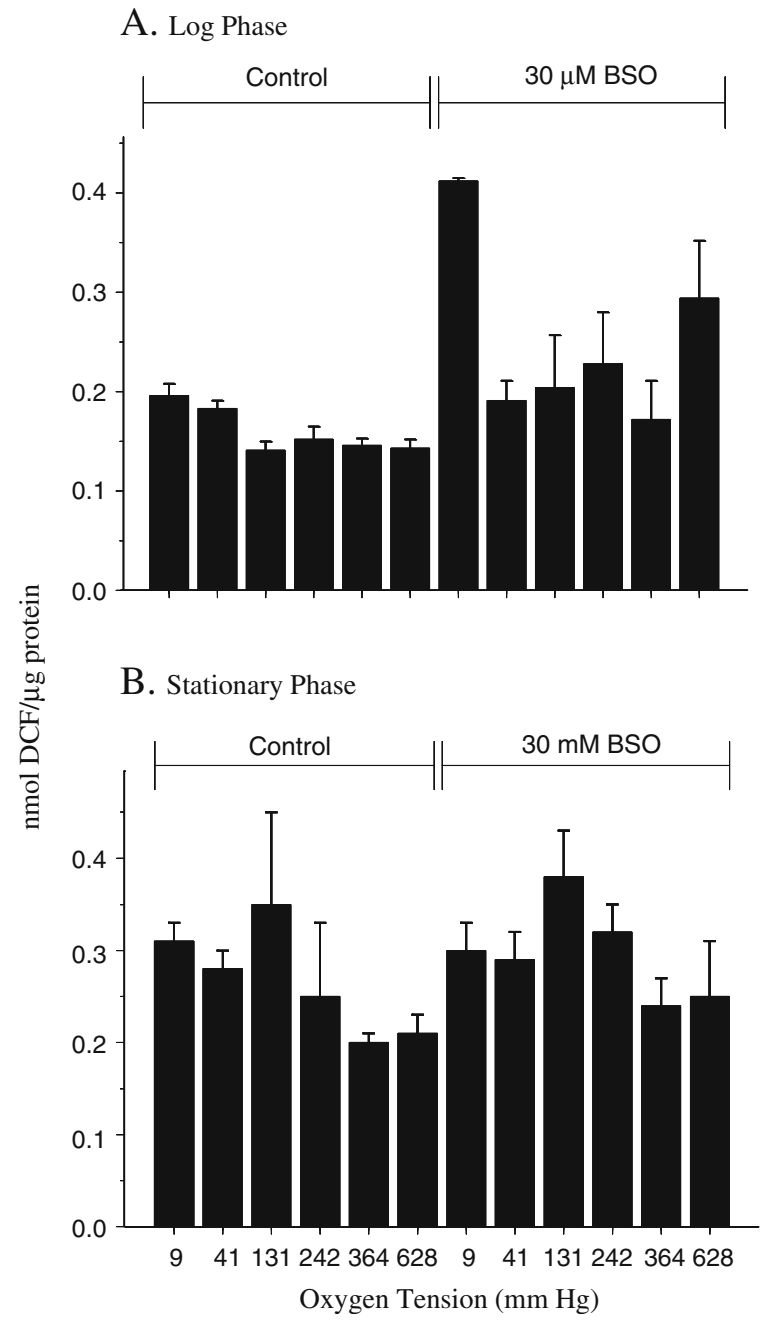

Fig. 6 ROS formation in WI-38 cultures exposed to different oxygen tensions for $24 \mathrm{~h}$. The cells were washed once with phenyl red, serum-free MEM and then treated with $100 \mu \mathrm{l}$ of DCFH-DA containing medium. The plates were incubated at $37^{\circ} \mathrm{C}$ for $1 \mathrm{~h}$. Following incubation, the cells were washed once with the wash buffer and read (ex 494, em 518) with a Victor 2 Plate Reader (Perkin Elmer) to determine the amount of oxidized DCF in the cells. Filters used were ex 485 (Perkin Elmer Filter 11440022) and em 535 (Perkin Elmer Filter 11440023). Protein in the samples was determined using Bradford protein assay reagent (Biorad). The reagent was diluted 1:5 with ultrapure water and filtered prior to treating samples. The Victor 2 plate reader was used to determine absorbance at $595 \mathrm{~nm}$. Each point is an average of eight determinations

SOD activity was constant in all of the cultures regardless of growth state or ambient oxygen tension. $\mathrm{Cu} / \mathrm{Zn} \mathrm{SOD}$ activity was diminished in senescent cultures; it remained insensitive to ambient oxygen tension. 
Of the antioxidant defenses examined, GSH was clearly the most responsive to changes in ambient oxygen concentration, and the response was greatest in actively growing cultures. GSH concentration has been reported to increase in other types of cells, such as hepatocytes, when they are stimulated to divide (Huang et al. 1998). Furthermore, large increases in GSH in response to hyperoxia have also been observed in vivo (Rister and Wustrow 1985; Langley and Kelly 1993) and in vitro (Allen and Balin 2003b). The increase in GSH concentration that we observed was particularly important in view of the relative lack of change of other antioxidant defenses. GSH is sometimes viewed as reacting too slowly to protect against free radicals (Winterbourn and Metodiewa 1999; Jones et al. 2003); however, the observation that hyperoxia greatly increases GSSG in the intact lung tissues of human newborns suggests that it reacts either directly with oxygen or with oxygen-centered reactive species (Vento et al. 2002). It should be noted that in fetal guinea pig lung, other sulfhydrylcontaining compounds such as $\mathrm{N}$-acetylcysteine protected against hyperoxic damage without significantly increasing GSH concentration above the level induced by the hyperoxia (Langley and Kelly 1993). Presumably, this effect is additive with GSH concentration.

GSH concentration was lowest in log-phase cultures maintained at $9 \mathrm{~mm} \mathrm{Hg}$ oxygen and ROS concentration was highest in these cells as compared with other cultures in log-phase growth. Also, GSH concentration was generally lower and oxidant concentration higher in contact-inhibited, growth-arrested cultures. The fact that the increase in GSH in logphase cultures in response to increased $\mathrm{O}_{2}$ was greater than observed in non-proliferating cultures may partly account for the failure of high oxygen tensions to produce large increases in ROS concentration. This hypothesis was further supported by the observation that inhibition of the GSH response with BSO resulted in a large increase in ROS concentration in log-phase cells, but not in stationary phase cultures, where the response of GSH to ambient oxygen tension is smaller. The decrease in GSH concentration observed in senescent cells maintained at oxygen tensions greater than $20 \%$ may partly explain the observation that MnSOD responded to high oxygen tension in these cells, but not in cultures that had increased GSH concentration in response to increasing oxygen tension.
In these studies, more fetal bovine serum was included in the growth medium than in the medium used to maintain stationary phase (10\% as compared to $0.5 \%$ see "Methods" section), and this may have affected GSH results. Merely adding medium that contains $10 \%$ serum to growth-arrested cells temporarily doubles GSH concentration at $20 \%$ oxygen, although no effect is observed in senescent cells. Nevertheless, non-proliferating confluent cultures refed with medium containing $0.5 \%$ serum exhibited similar levels of GSH as cells maintained in $10 \%$ serum after $24-\mathrm{h}$ exposure to $20 \%$ oxygen.

The large change in GSH concentration in response to elevation in oxygen tension may have also influenced other antioxidant capacities. For example, our result revealed no change in the CDNB-reactive form of the GSH $S$-transferases; however, the kinetics of the $S$-transferases is strongly dependent on the concentration of GSH. In the assay mixture, activity was proportional to GSH concentrations up to $4 \mathrm{mM}$. Similar observations have been reported in other organisms (van Hylckama Vlieg et al. 1999). In our standard assay, the $5 \mathrm{mM}$ GSH concentration was in excess, and thus, GSH was never a limiting factor in the reaction. In intact cells, GSH concentration varied by more than an order of magnitude between hypoxic and hyperoxic environments and was well below the concentration that gave a plateau in $S$-transferase activity in vitro. Thus, while the amount of $S$ transferase protein was relatively constant, it is probable that $S$-transferase activity in intact cells varied dramatically as the ambient oxygen tension (and GSH concentration) was increased.

G-6-PD and GR activities both appeared to be independent of GSH concentration although the maintenance of GSH concentration is strongly dependent on these enzymes in vivo. The most probable explanation for this apparent discrepancy is the artificially low level of GSSG that remains in tissue culture cells. It is in fact the oxidized form of glutathione that activates both of these enzymes (Eggleston and Krebs 1974; Carlberg and Mannervik 1985). Since cell membranes are permeable to GSSG and since, in the culture environment, a large volume of medium surrounds the cells, simple diffusion keeps cellular GSSG at artificially low levels as compared to cells in intact tissues. Thus, cellular responses dependent on GSSG concentration should to some extent differ between in vivo and in vitro cellular environments. 
We previously determined that catalase activity in fetal fibroblasts is very low and that it is strongly inhibited under hyperoxic conditions (Balin et al. $2002 b$ ). Due to its low activity and its relatively high $K_{\mathrm{M}}$ (Nicholls et al. 2001), catalase is probably not a significant factor in the removal of peroxides from proliferatively young cells. GSH peroxidase activity is also relatively low in human cells, but it exhibits a much lower $K_{\mathrm{M}}$ than catalase, which may increase its importance in elimination of endogenously produced hydrogen peroxide. Indeed, overexpression of GPx-1 has been found to increase resistance to oxygen toxicity (Ho and Howard 1992; Faucher et al. 2003; Modrick et al. 2009), and GPx activity is often stimulated by hyperoxia in the tissues of intact animals (White et al. 1988; Taylor and Bray 1991; Knickelbein et al. 1996). In young cultures, GPx-1 activity was suppressed by both hypoxia and hyperoxia. This suggests that at lower levels of oxygen (131 mm Hg), GPx-1 activity is inducible. Above $242 \mathrm{~mm} \mathrm{Hg}$ oxygen, it decreased probably because of inactivation. The inhibition of $\mathrm{H}_{2} \mathrm{O}_{2}$ metabolizing enzymes by hyperoxia is consistent with increased superoxide generation since GPx contains several sensitive -SH groups needed for activity (Flohé 1982) that can be oxidized by superoxide (Blum and Fridovich 1985).

GPx activity declined as a function of ambient oxygen tension in senescent cells; however, catalase activity is elevated more than 3-fold in WI-38 cells that have senesced (Allen et al. 1999). This suggests that catalase may have a more significant role in the protection of senescent cells. Senescent cultures also produce 3-fold more $\mathrm{H}_{2} \mathrm{O}_{2}$ and $60 \%$ more superoxide than young cells (Allen et al. 1999), which further supports the hypothesis that lower GPX-1 activity in late passage cells results from inactivation rather than a decline in synthesis.

Hyperoxia has frequently been reported to increase SOD activity in animal tissues after prolonged exposure (Kimball et al. 1976; Housset and Junod 1982; Freeman et al. 1986; Webster et al. 1987; Taylor and Bray 1991; also see Allen and Balin 1989 for review). Increases in $\mathrm{Cu} / \mathrm{Zn} \mathrm{SOD}$ activity have Taylor and Bray 1991 also been reported in some types of human cell culture, such as human umbilical vein endothelial cells exposed to hyperoxia (Jornot and Junod 1992); however, neither form of SOD responded to variations in oxygen tension in the early passage WI-38 cultures examined. MnSOD activity was affected by growth state, proliferative age, and time. The fact that SOD activity was not induced by hyperoxia in young cell cultures raises the question of whether it is unable to respond due to factors in the culture environment or if oxygen toxicity in these cells is more dependent on factors other than increased superoxide generation. Previous studies have demonstrated that addition of the superoxide generating herbicide paraquat to medium increases MnSOD activity in both normal and virally transformed WI-38 cells (Allen and Balin 2003b), indicating that a significant increase in superoxide will stimulate SOD activity. The observation that oxygen fails to increase the activity of SOD in WI-38 cells even though SOD activity is clearly responsive to other treatments that increase superoxide generation leads us to infer that the toxicity of elevated partial pressures of oxygen are ameliorated at least partly by responses of other antioxidant defenses. Of course, in the case of WI-38 cells, the possibility remains that other factors that contribute to oxygen toxicity also block signaling pathways that lead to the induction of SOD activities. We previously observed that inhibition of GSH synthesis in WI-38 cells under normoxic conditions was sufficient to cause a modest increase in MnSOD activity (Allen and Balin 2003b). An examination of steady-state levels of ROS using DCF formation revealed greater concentrations of ROS in log-phase cultures maintained under lower oxygen tensions. This observation suggests that the electron transport chains of mitochondria are sufficiently reduced to produce oxidants only at lower oxygen tensions. At higher oxygen tensions, electrons may be stripped from cytochromes with the result that they exist in a predominantly oxidized state and thus generate fewer radicals (Boveris and Cadenas 1982; Forman and Boveris 1982). A complete analysis of hyperoxia on mitochondrial function was beyond the scope of this study but will be presented elsewhere.

Several studies have demonstrated a strong and nearly immediate effect of oxygen on the cell cycle of WI-38 cells (Balin et al. 1976, 1978, 1984; Balin and Pratt 2002). The observation that oxygen tensions that dramatically affect cell growth fail to induce the antioxidant defense enzymes suggests that the effects of oxygen on cell growth are the result of specific cellular interactions rather than random free radical interactions with cell components. 
The results of this study revealed that GSH concentration changed dramatically in human fetal fibroblasts exposed to hyperoxia, while other antioxidant defenses tended to be relatively unresponsive under the conditions used. Several of the antioxidant defenses were far more responsive to growth state or proliferative age than to the ambient oxygen environment. The fact that the tissue culture environment tended to artificially decrease GSSG may account for the failure of some antioxidant defenses to respond to hyperoxia. The results of this and previous studies collectively demonstrate that antioxidant defense levels are more strongly modulated by growth state than by oxygen tension and that senescent cells, which exhibit an impaired GSH response, tend to be more oxidized than young cultures.

Acknowledgments This work was partially supported by PHS grant Nos. AG00282 AG04993 and AG05346 and the John A. and George L. Hartford Foundation. This research was also supported by a General Clinical Research Center Grant (RR00102) from The National Institutes of Health to The Rockefeller University Hospital and with general support from the Pew Trusts. The project was also funded, in part, under a grant with the Pennsylvania Department of Health. The department specifically disclaims responsibility for any analyses, interpretations, or conclusions. Additional funding was provided by the Longevity Achievement Foundation (Media, PA). We also wished to acknowledge the contribution of the late Professor D. Martin Carter, who provided a laboratory environment that made this research possible.

Open Access This article is distributed under the terms of the Creative Commons Attribution Noncommercial License which permits any noncommercial use, distribution, and reproduction in any medium, provided the original author(s) and source are credited.

\section{References}

Allen RG (1998) Oxidative stress and superoxide dismutase in development, aging and gene regulation. Age 21:47-76

Allen RG, Balin AK (1989) Oxidative influence on development and differentiation: an overview of a free radical theory of development. Free Radic Biol Med 6:631-661

Allen RG, Balin AK (2003a) Metabolic rate, free radicals and aging. In: Cutler RG, Rodriguez $\mathrm{H}$ (eds) Metabolic rate free radicals and aging: advances in basic science, diagnostics, and intervention. World Scientific, New York, pp 3-23

Allen RG, Balin AK (2003b) Effects of oxygen on the antioxidant responses of normal and transformed cells. Exp Cell Res 289:207-316

Allen RG, Keogh BP, Gerhard G, Pignolo R, Horton J, Cristofalo VJ (1995) Expression and regulation of SOD activity in human skin fibroblasts from donors of different ages. J Cell Physiol 165:576-587

Allen RG, Tresini M, Keogh BP, Doggett DL, Cristofalo VJ (1999) Differences in electron transport potential antioxidant defenses and oxidant generation in young and senescent fetal lung fibroblasts (WI-38). J Cell Physiol 180:114-122

Allsopp RC, Harley CB (1995) Evidence for a critical telomere length in senescent human fibroblasts. Exp Cell Res 219:130-136

Arsova-Sarafinovska Z, Matevska N, Eken A, Petrovski D, Banev S, Dzikova S, Georgiev V, Sikole A, Erdem O, Sayal A, Aydin A, Dimovski AJ (2009) Glutathione peroxidase 1 (GPX1) genetic polymorphism, erythrocyte GPX activity, and prostate cancer risk. Int Urol Nephrol 41:63-70

Auten RL, Davis JM (2009) Oxygen toxicity and reactive oxygen species: the devil is in the details. Pediatr Res 66:121-127

Balin AK, Pratt L (2002) Oxygen modulates the growth of skin fibroblasts. In Vitro Cell Dev Biol Anim 38:305-310

Balin AK, Goodman DG, Rassmussen H, Cristofalo VJ (1976) The effect of oxygen tension on the growth and metabolism of WI-38 cells. J Cell Physiol 89:235-250

Balin AK, Goodman DB, Rasmussen H, Cristofalo VJ (1978) Oxygen-sensitive stages of the cell cycle of human diploid cells. J Cell Biol 78:390-400

Balin AK, Fisher AJ, Carter DM (1984) Oxygen modulates growth of human cells at physiologic partial pressures. J Exp Med 160:152-166

Balin AK, Fisher AJ, Anzelone M, Leong I, Allen RG (2002a) Effects of establishing cell cultures and cell culture conditions on the proliferative life span of human fibroblasts isolated from different tissues and donors of different ages. Exp Cell Res 274:275-287

Balin AK, Pratt L, Allen RG (2002b) Effects of ambient oxygen concentration on the growth and antioxidant defenses of human cell cultures established from fetal and postnatal skin. Free Radic Biol Med 32:257-267

Bass DA, Parce JW, DeChatelet LR, Szejda P, Seeds MC, Thomas M (1983) Flow cytometric studies of oxidative product formation by neutrophils: a graded response to membrane stimulation. J Immunol 130:1910-1917

Beckman KB, Ames BN (1998) The free radical theory of aging matures. Physiol Rev 78:547-581

Blum J, Fridovich I (1985) Inactivation of glutathione peroxidase by superoxide radical. Arch Biochem Biophys 240:500-508

Boveris A, Cadenas E (1982) Production of superoxide radicals and hydrogen peroxide in mitochondria. In: Oberley LW (ed) Superoxide dismutase. CRC, Boca Raton, pp 16-30

Carlberg I, Mannervik B (1985) Glutathione reductase. In: Colowick SP, Kaplan NO, Meister A (eds) Methods in enzymology. Academic, New York, pp 485-490

Carter WO, Narayanan PK, Robinson JP (1994) Intracellular hydrogen peroxide and superoxide anion detection in endothelial cells. J Leukoc Biol 55:253-258

Chiou TJ, Tzeng WF (2000) The roles of glutathione and antioxidant enzymes in menadione-induced oxidative stress. Toxicology 154:75-84

Cristofalo VJ, Volker C, Allen RG (2000) Use of the fibroblast model in the study of cellular senescence. In: Barnett Y, 
Barnett CR (eds) Aging methods and protocols. Humana Press, Totowa, pp 23-52

Cristofalo VJ, Lorenzini A, Allen RG, Torres C, Tresini M (2004) Replicative senescence: a critical review. Mech Ageing Dev 125:827-848

Davies KJ (1999) The broad spectrum of responses to oxidants in proliferating cells: a new paradigm for oxidative stress. IUBMB Life 48:41-47

Davies KJ (2000) Oxidative stress, antioxidant defenses, and damage removal, repair, and replacement systems. IUBMB Life 50:279-289

Deutsch J (1980) Glucose-6-phosphate dehydrogenase. In: Bergmeyer $\mathrm{H}$ (ed) Methods in enzymatic analysis. Academic, New York, pp 190-197

Eggleston EV, Krebs H (1974) Regulation of the pentose phosphate cycle. Biochem J 138:425-435

Faucher K, Rabinovitch-Chable H, Barriere G, Cook-Moreau J, Rigaud M (2003) Overexpression of cytosolic glutathione peroxidase (GPX1) delays endothelial cell growth and increases resistance to toxic challenges. Biochimie 85:611-617

Flohé L (1982) Glutathione peroxidase brought into focus. In: Pryor WA (ed) Free radicals in biology. Academic, New York, pp 223-254

Forman HJ, Boveris A (1982) Superoxide radical and hydrogen peroxide in mitochondria. In: Pryor WA (ed) Free radicals in biology. Academic, New York, pp 65-90

Freeman BA, Mason RJ, Williams MC, Crapo JD (1986) Antioxidant enzyme activity in alveolar type II cells after exposure of rats to hyperoxia. Exp Lung Res 10:203-222

Freshney RI (1994) Culture of animal cells. Wiley, New York

Greabu M, Battino M, Mohora M, Olinescu R, Totan A, Didilescu A (2008) Oxygen, a paradoxical element? Rom J Intern Med 46:125-135

Griffith OW (1980) Determination of glutathione and glutathione disulfide using glutathione reductase and 2-vinylpyridine. Anal Biochem 106:207-212

Harley CB, Futcher AB, Greider CW (1990) Telomeres shorten during aging of human fibroblasts. Nature 345:458-460

Hazelton GA, Lang CA (1983) Glutathione $S$-transferase activity in the yellow-fever mosquito [Aedes aegypti (Louisville)] during growth and aging. Biochem J 210:281-287

Ho YS, Howard AJ (1992) Cloning and characterization of the rat glutathione peroxidase gene. FEBS Lett 301:5-9

Housset B, Junod AF (1982) Effects of culture conditions and hyperoxia on antioxidant enzymes in pig pulmonary artery and aortic endothelium. Biochim Biophys Acta 716:283-289

Huang ZZ, Li H, Cai J, Kuhlenkamp J, Kaplowitz N, Lu SC (1998) Changes in glutathione homeostasis during liver regeneration in the rat. Hepatology 27:147-153

Jones CM, Lawrence A, Wardman P, Burkitt MJ (2003) Kinetics of superoxide scavenging by glutathione: an evaluation of its role in the removal of mitochondrial superoxide. Biochem Soc Trans 31:1337-1339

Jornot L, Junod AF (1992) Response of human endothelial cell antioxidant enzymes to hyperoxia. Am J Respir Cell Mol Biol 6:107-115

Keogh BP, Allen RG, Pignolo R, Horton J, Tresini M, Cristofalo VJ (1996) Expression of hydrogen peroxide and glutathione metabolizing enzymes in human skin fibroblasts derived from donors of different ages. J Cell Physiol 167:512-522

Kimball RE, Reddy K, Peirce TH, Schwartz LW, Mustafa MG, Cross CE (1976) Oxygen toxicity: augmentation of antioxidant defense mechanisms in rat lung. Am J Physiol 230:1425-1431

Knickelbein RG, Ingbar DH, Seres T, Snow K, Johnston RB Jr, Fayemi O, Gumkowski F, Jamieson JD, Warshaw JB (1996) Hyperoxia enhances expression of gamma-glutamyl transpeptidase and increases protein S-glutathiolation in rat lung. Am J Physiol 270:L115-L122

Langley SC, Kelly FJ (1993) $N$-acetylcysteine ameliorates hyperoxic lung injury in the preterm guinea pig. Biochem Pharmacol 45:841-846

Legan SK, Rebrin I, Mockett RJ, Radyuk SN, Klichko VI, Sohal RS, Orr WC (2008) Overexpression of glucose-6phosphate dehydrogenase extends the life span of Drosophila melanogaster. J Biol Chem 283:32492-32499

Liochev SI, Fridovich I (2001) Copper, zinc superoxide dismutase as a univalent $\mathrm{NO}(-)$ oxidoreductase and as a dichlorofluorescin peroxidase. J Biol Chem 276:35253-35257

Mattar EH, Haffor AS (2009) Effect of dobutamine and hyperoxia on free radicals production in relation to the ultrastructural alterations in the endothelial of myocardial capillary in rats, Rattus norvigicus. Ultrastruct Pathol 33:209-215

Misra HP, Fridovich I (1977) Superoxide dismutase a photochemical augmentation assay. Arch Biochem Biophys 181:308-312

Modrick ML, Didion SP, Lynch CM, Dayal S, Lentz SR, Faraci FM (2009) Role of hydrogen peroxide and the impact of glutathione peroxidase-1 in regulation of cerebral vascular tone. J Cereb Blood Flow Metab 29:1130-1137

Nicholls P, Loewen P, Fita I (2001) Enzymology and structure of catalases. In: Sykes AG, Mauk G (eds) Advances in inorganic chemistry. Heme-Fe proteins. Academic, New York, pp 52-106

Parrinello S, Samper E, Krtolica A, Goldstein J, Melov S, Campisi J (2003) Oxygen sensitivity severely limits the replicative lifespan of murine fibroblasts. Nat Cell Biol 5:741-747

Patel DN, Goel A, Agarwal SB, Garg P, Lakhani KK (2003) Oxygen toxicity. J Indian Acad Clin Med 4:234-237

Ran Q, Gu M, Van Remmen H, Strong R, Roberts JL, Richardson A (2006) Glutathione peroxidase 4 protects cortical neurons from oxidative injury and amyloid toxicity. J Neurosci Res 84:202-208

Rancourt RC, Hayes DD, Chess PR, Keng PC, O'Reilly MA (2002) Growth arrest in G1 protects against oxygen-induced DNA damage and cell death. J Cell Physiol 193:26-36

Rister M, Wustrow C (1985) Effect of hyperoxia on reduced glutathione in alveolar macrophages and polymorphonuclear leukocytes. Res Exp Med (Berl) 185:445-450

Rothe G, Valet G (1990) Flow cytometric analysis of respiratory burst activity in phagocytes with hydroethidine and 2',7'-dichlorofluorescin. J Leukoc Biol 47:440-448

Rothe G, Valet G (1994) Flow cytometric analysis of oxidative burst activity in phagocytes. Meth Enzymol 233:5-548

Schneider EL, Stanbridge EJ (1975) A simple biochemical technique for the detection of mycoplasma contamination of cultured cells. Meth Cell Biol 10:277-290 
Stogner SW, Payne DK (1992) Oxygen toxicity. Ann Pharmacother 26:1554-1562

Taylor CG, Bray TM (1991) Increased lung copper-zincsuperoxide dismutase activity and absence of magnetic resonance imaging-detectable lung damage in copperdeficient rats exposed to hyperoxia. J Nutr 121:467-473

Tietze F (1969) Enzymatic method for quantitative determination of nanogram amounts of total and oxidized glutathione: application to mammalian blood and other tissues. Anal Biochem 27:502-522

van Hylckama Vlieg JE, Kingma J, Kruizinga W, Janssen DB (1999) Purification of a glutathione $S$-transferase and a glutathione conjugate-specific dehydrogenase involved in isoprene metabolism in Rhodococcus sp. strain AD45. J Bacteriol 181:2094-2101

Vento M, Asensi M, Sastre J, Lloret A, Garcia-Sala F, Minana JB, Vina J (2002) Hyperoxemia caused by resuscitation with pure oxygen may alter intracellular redox status by increasing oxidized glutathione in asphyxiated newly born infants. Semin Perinatol 26:406-410

von Zglinicki T, Saretzki G, Döcke W, Lotze C (1995) Mild hyperoxia shortens telomeres and inhibits proliferation of fibroblasts: a model for senescence? Exp Cell Res 220: 186-192

von Zglinicki T, Pilger R, Sitte N (2000) Accumulation of singlestrand breaks is the major cause of telomere shortening in human fibroblasts. Free Radic Biol Med 28:64-74

Webster NR, Toothill C, Cowen PN (1987) Tissue responses to hyperoxia. Biochemistry and pathology. Br J Anaesth 59:760-771

White CW, Jackson JH, McMurtry IF, Repine JE (1988) Hypoxia increases glutathione redox cycle and protects rat lungs against oxidants. J Appl Physiol 65:2607-2616

Winterbourn CC, Metodiewa D (1999) Reactivity of biologically important thiol compounds with superoxide and hydrogen peroxide. Free Radic Biol Med 27:322-328 